\title{
New Oxoprotoberberine and Aporphine Alkaloids from the Roots of Amoora cucullata with Their Antiproliferative Activites
}

\author{
Parinuch Chumkaew ${ }^{*}$, Passakorn Teerapongpisan $\odot$, \\ Jaraslak Pechwang and Theera Srisawat \\ Faculty of Science and Industrial Technology, Prince of Songkla University, Suratthani \\ Campus, Suratthani 84000, Thailand
}

(Received February 08, 2019; Revised April 06, 2019; Accepted April 08, 2019)

\begin{abstract}
Two new oxoprotoberberine alkaloids, amocurine A and B (1 and 2), a new aporphine alkaloid, amocurine $C(3)$, along with three known compounds (4-6) were isolated from the roots of Amoora cucullata. Their structures were determined by analysis of spectroscopic data. The isolated compounds were evaluated for their antiproliferative activity against three human cancer cell lines (KB, oral cavity; MCF-7, breast cancer; and NCI-H187, small cell lung cancer). Compounds 3 showed the most potent activities against KB and MCF-7 cell lines with $\mathrm{IC}_{50}$ values 3.5 and $4.2 \mu \mathrm{M}$, respectively.
\end{abstract}

Keywords: Oxoprotoberberine; aporphines; antiproliferative activity; Amoora cucullata. (C) 2019 ACG Publications. All rights reserved.

\section{Introduction}

Amoora cucullata is a mangrove plant belonging to the family Meliaceae and occurs naturally in the coastal areas of Southeast Asia and the Indian Ocean. This plant has been used as a folk medicine for the treatment of marrow and diarrhea [1]. The leaves are traditionally used to treat inflammation, skin diseases, and cardiac diseases [2-3]. As part of our continuing research on Thai medicinal plants [4-8], a phytochemical study on the roots of A. cucullata was carried out. Previous investigation on the fruits of $A$. cucullata reported two new rocaglamide derivatives [9]. In continuation of our phytochemical screening of $A$. cucullata roots, we report the isolation and structure elucidation of two new oxoprotoberberine alkaloids, amocurine A and B (1 and 2), a new aporphine alkaloid, amocurine C (3), together with three known compounds, dehydrodicentrine (4) [10], stephanine (5) [11], and roemerine (6) [11] (Figure 1). The structures of the compounds were determined by spectroscopic data including 1D and 2D NMR and by comparison with those published in the literature [12-14]. Furthermore, all the isolated alkaloids were in vitro evaluated for their antiproliferative potential activities.

\footnotetext{
*Corresponding author: E-Mail: parinuch.c@gmail.com; Phone: +66-7735-5040.
} 
<smiles>COc1cc2c(cc1OC)-c1cc3c(OC)ccc(O)c3c(=O)n1CC2</smiles>

1<smiles>COc1cc2c(cc1OC)C1Cc3ccc(OC)c(O)c3C(=O)N1CC2</smiles>

2<smiles>COc1ccc2c(C=O)c3c4c(cc5c(c4c2c1OC)OCO5)CCN3C</smiles>

3<smiles></smiles>

4<smiles>[R]c1cccc2c1CC1c3c([R])cccc3-c3c4c(cc(c31)CCN2C)OCO4</smiles>

$5 \mathrm{R}_{1}=\mathrm{OCH}_{3}$

$6 \mathrm{R}_{1}=\mathrm{H}$

Figure 1. Structures of compounds 1-6 isolated from Amoora cucullata

\section{Materials and Methods}

\subsection{General Experimental Procedures}

Optical rotations were determined on a Rudolph (Hackettstown, NJ, USA) Autopol II automatic polarimeter. UV spectra were measured with a UV-160A spectrophotometer (Shimadzu, Kyoto, Japan), and IR spectra were recorded on a Perkin-Elmer 1750 FTIR spectrophotometer (Perkin-Elmer, Waltham, MA, USA). The ${ }^{1} \mathrm{H}$ and ${ }^{13} \mathrm{C}-\mathrm{NMR}$ spectra were recorded in $\mathrm{CDCl}_{3}$ using a $500 \mathrm{MHz}$ Varian Unity INOVA spectrometer. Chemical shifts are recorded in parts per million $(\delta)$ in $\mathrm{CDCl}_{3}$. Mass spectra (EI or FAB) were recorded on a Finnigan-MAT 95 XL spectrometer. Thin-layer chromatography (TLC) was performed on silica gel $60 \mathrm{GF}_{254}$ (Merck). Column chromatography was carried out on silica gel $60 \mathrm{GF}_{254}$ (Merck, Darmstadt, Germany). All solvents for extraction and chromatography were routinely distilled prior to use.

\subsection{Plant Material}

The roots of Amoora cucullata were collected from Khanom, Nakhon Si Thammarat, Thailand, in May 2010. A voucher specimen (number WU-0145) was deposited in the herbarium of Walailak University, Thasala, Nakhon Si Thammarat, Thailand.

\subsection{Extraction and Isolation}

The roots of $A$. cucullata $(0.8 \mathrm{~kg})$ were extracted three times by maceration with acetone at room temperature. Removal of the solvent under reduced pressure provided a crude extract $(8.2 \mathrm{~g})$. The acetone extract was separated by column chromatography over silica gel and eluted with a gradient of hexane-EtOAc to afford nine fractions (R1-R9). Fraction R2 (860 mg) was purified by CC on silica gel using isocratic eluted with EtOAc-hexane (1:4) to give four subfractions R2A to R2D. Subfraction R2B (120 mg) was purified over Sephadex LH-20 with $\mathrm{MeOH}$ to provide compound 4 
(11.4 mg). Fraction R3 (650 mg) was subjected to a silica gel column eluted with EtOAc-hexane (1:9) to yield compound $3(10.8 \mathrm{mg})$. Fraction R4 (1.6 g) was purified by CC using EtOAc-hexane (1:2) to provide five subfractions (R4A-R4E). Compounds $5(9.8 \mathrm{mg})$ and $\mathbf{6}(10.5 \mathrm{mg})$ were derived from fraction R4C (380 mg) by CC using EtOAc-hexane (1:4) as eluent. Fraction R6 (1.2 g) was separated by $\mathrm{CC}$ on a silica gel with solvent mixtures EtOAc-hexane (1:4) to give five subfractions (R6A-R6E). Subfraction R6B (145 mg) was further purified over Sephadex LH-20 with MeOH to afford compound $1(10.8 \mathrm{mg})$. Fraction R7 (1.1 g) was eluted with EtOAc-hexane (1:9) yielding compound 2 (15.4 mg) after purification by CC and preparative TLC.

\subsection{Spectroscopic Data}

Amocurine A (1): Brownish-red gum; IR $v_{\max }\left(\mathrm{KBr}, \mathrm{cm}^{-1}\right)$ : 3420, 1647, 1590, and 1514; UV (MeOH, nm) $\lambda_{\max }(\log \varepsilon): 251(2.95), 338(1.90) ;{ }^{1} \mathrm{H}\left(500 \mathrm{MHz}, \mathrm{CDCl}_{3}\right)$ and ${ }^{13} \mathrm{C}$ NMR $\left(125 \mathrm{MHz}, \mathrm{CDCl}_{3}\right)$ spectral data, see Table 1 and 2; HRESIMS $m / z 354.1339[\mathrm{M}+\mathrm{H}]^{+}$(calcd. for $\mathrm{C}_{20} \mathrm{H}_{20} \mathrm{NO}_{5}: 354.1341$ ).

Amocurine B (2): Brownish-red gum; $[\alpha]_{D}^{28}-97(c 0.02, \mathrm{MeOH}) ; \mathrm{IR} v_{\max }\left(\mathrm{KBr}, \mathrm{cm}^{-1}\right)$ : 3421,1635 , 1590 and 1502; UV (MeOH, nm) $\lambda_{\max }(\log \varepsilon): 251(2.95), 388(1.90) ;{ }^{1} \mathrm{H}\left(500 \mathrm{MHz}, \mathrm{CDCl}_{3}\right)$ and ${ }^{13} \mathrm{C}$ NMR $\left(125 \mathrm{MHz}, \mathrm{CDCl}_{3}\right)$ spectral data, see Table 1 and 2; HRESIMS $m / z 356.1494[\mathrm{M}+\mathrm{H}]^{+}$(calcd. for $\left.\mathrm{C}_{20} \mathrm{H}_{22} \mathrm{NO}_{5}: 356.1498\right)$.

Amocurine C (3): Dark brown gum; IR $v_{\max }\left(\mathrm{KBr}, \mathrm{cm}^{-1}\right)$ : 1684, 1592, and 1512; UV (MeOH, nm) $\lambda_{\max }$ : 265 (4.76), 329 (4.21); ${ }^{1} \mathrm{H}\left(500 \mathrm{MHz}, \mathrm{CDCl}_{3}\right)$ and ${ }^{13} \mathrm{C} \mathrm{NMR}\left(125 \mathrm{MHz}, \mathrm{CDCl}_{3}\right)$ spectral data, see Table 1 and 2; HRESIMS $m / z 366.1345[\mathrm{M}+\mathrm{H}]^{+}$(calcd. for $\mathrm{C}_{21} \mathrm{H}_{20} \mathrm{NO}_{5}$ : 366.1341).

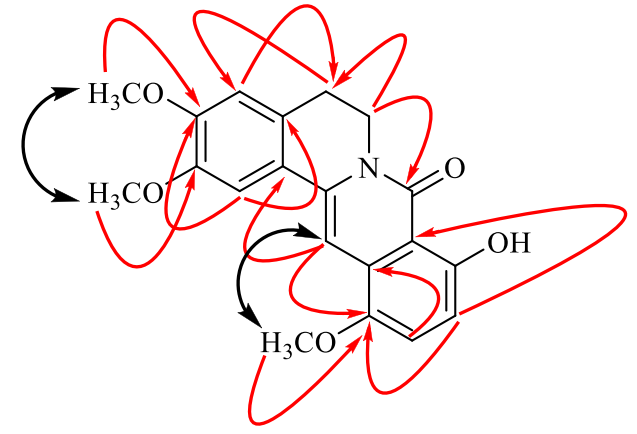

1

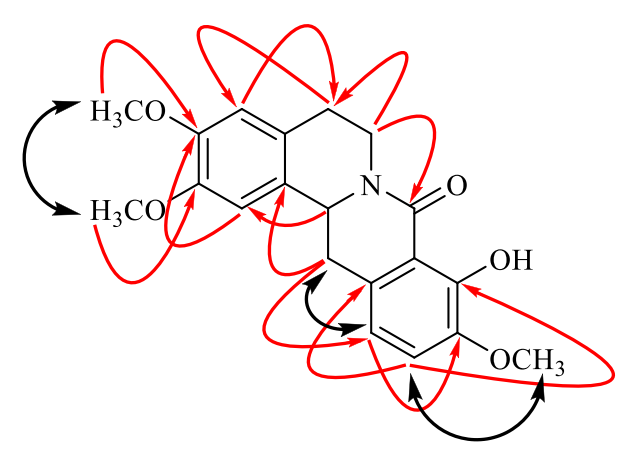

2

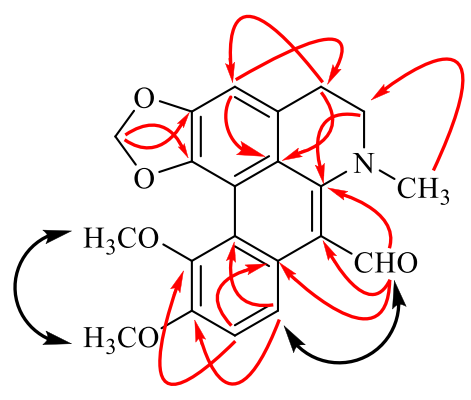

3

Figure 2. Key HMBC (arrow curves) and NOESY $(\longleftrightarrow$ ) correlations of compounds 1-3 


\subsection{Antiproliferative Activity Assay}

Human breast carcinoma cell line (MCF-7), human lung carcinoma cell line (NCI$\mathrm{H} 187$ ), and human oral epidermal carcinoma cell line (KB) were obtained from the Bioassay Laboratory, BIOTEC, NSTDA, Pathumthani, Thailand. The MCF-7, NCI-H187, and KB cells were maintained in RPMI 1640 and low glucose DMEM medium, respectively, supplemented with $10 \%$ fetal bovine serum and incubated under standard conditions $\left(37{ }^{\circ} \mathrm{C}, 5 \% \mathrm{CO}_{2}\right)$. The isolated compounds were diluted to the desired concentration $(80,40,20,10$ and $5 \mu \mathrm{g} / \mathrm{ml})$ in the medium. The cultures were incubated for $72 \mathrm{~h}$ with the test compounds.

MTT assay, as described by Vichai et al. [15], was employed to determine cell viability. After $72 \mathrm{~h}$ of incubation, $100 \mu \mathrm{l}$ of $0.5 \mathrm{mg} / \mathrm{ml}$ MTT reagent was added into each well, and incubated for $30 \mathrm{~min}$ in a $\mathrm{CO}_{2}$ incubator. MTT solution was then discarded and 100 $\mu$ dimethyl sulfoxide (DMSO) was added into each well to solubilize the cells and dissolve the color substance. For complete solubilization, the plates were vigorously agitated for $5 \mathrm{~min}$ at room temperature, and then measured on a microplate reader at a wavelength of $570 \mathrm{~nm}$. MTT solution with only DMSO was used as the blank, while Ellipticine and Doxorubicin were the positive controls. Each assay was performed with three replications. A calibration curve based on optical density was constructed from which growth inhibition was determined. The $50 \%$ growth inhibition concentrations $\left(\mathrm{IC}_{50}\right)$ of the pure compounds were calculated from fitted response curves.

\section{Results and Discussion}

\subsection{Structure Elucidation}

Amocurine A (1) was isolated as a brownish-red gum with the molecular formula $\mathrm{C}_{20} \mathrm{H}_{20} \mathrm{NO}_{5}$ as determined by HRESIMS of the $[\mathrm{M}+\mathrm{H}]^{+}$ion at $\mathrm{m} / \mathrm{z}$ 354.1339. The UV spectrum displayed absorption bands at 251 and $338 \mathrm{~nm}$, and the IR spectrum revealed the presence of one hydroxyl group $\left(3420 \mathrm{~cm}^{-1}\right)$, a conjugated amide $\left(1647 \mathrm{~cm}^{-1}\right)$, and an aromatic ring system $\left(1590\right.$ and $\left.1514 \mathrm{~cm}^{-1}\right)$, indicating the presence of an oxoprotoberberine-type alkaloid [16]. An important feature for this oxoprotoberberine alkaloid in the ${ }^{1} \mathrm{H}-\mathrm{NMR}$ spectrum was a downfield-shifted proton at $\delta_{\mathrm{H}} 4.27(\mathrm{t}, J=$ $6.0 \mathrm{~Hz}, \mathrm{H}-6)$ caused by the deshielding effect of the amide and the anisotropic effect of the C-8 carbonyl group. The ${ }^{1} \mathrm{H}$ NMR spectrum of $\mathbf{1}$ (Table 1) showed resonances for a chelated hydroxyl group $\left(\delta_{\mathrm{H}} 13.15\right.$, br s), two ortho-coupled aromatic protons at $\delta_{\mathrm{H}} 7.36(\mathrm{~d}, J=8.4 \mathrm{~Hz}, \mathrm{H}-10)$ and 7.02 $(\mathrm{d}, J=8.4 \mathrm{~Hz}, \mathrm{H}-11)$, two singlet aromatic protons at $\delta_{\mathrm{H}} 6.84(\mathrm{H}-1)$ and $6.64(\mathrm{H}-4)$, one set of coupled methylene protons at $\delta_{\mathrm{H}} 4.27(\mathrm{t}, J=6.0 \mathrm{~Hz}, \mathrm{H}-6)$, and $2.94(\mathrm{t}, J=6.0 \mathrm{~Hz}, \mathrm{H}-5)$, and three methoxy groups at $\delta_{\mathrm{H}} 3.96\left(\mathrm{~s}, \mathrm{OCH}_{3}-2\right), 3.88\left(\mathrm{~s}, \mathrm{OCH}_{3}-12\right)$, and $3.84\left(\mathrm{~s}, \mathrm{OCH}_{3}-3\right)$.

Compound 1 showed resonances for an amide carbonyl $\left(\delta_{\mathrm{C}} 166.3\right)$, nine quaternary carbons $\left(\delta_{\mathrm{C}} 154.3,152.7,148.1,147.8,134.5,127.7,126.3,122.8\right.$, and 111.6), two methylene carbons $\left(\delta_{\mathrm{C}} 39.1\right.$ and 29.4) and three methoxy carbons $\left(\delta_{\mathrm{C}} 62.3,60.8\right.$, and 56.2) in the ${ }^{13} \mathrm{C}-\mathrm{NMR}$ and DEPT spectra (Table 2). The HMBC correlation (Figure 2$)$ between H-6 $\left(\delta_{\mathrm{H}} 4.27\right)$ and a carbon resonance at $\delta_{\mathrm{C}}$ 166.3 suggested that an amide carbonyl was positioned at C-8. The chelated hydroxyl proton at $\delta_{\mathrm{H}}$ 13.15 was located at $\mathrm{C}-9\left(\delta_{\mathrm{C}} 148.1\right)$ due to being hydrogen bonded to the amide carbonyl carbon at $\mathrm{C}$ $8\left(\delta_{\mathrm{C}} 166.3\right)$. Two ortho-coupled aromatic protons at $\delta_{\mathrm{H}} 7.36$ and 7.02 were assigned to $\mathrm{H}-10\left(\delta_{\mathrm{C}}\right.$ $123.1)$ and $\mathrm{H}-11\left(\delta_{\mathrm{C}} 116.7\right)$, respectively, on the basis of the correlations of $\mathrm{H}-10$ with $\mathrm{C}-8 \mathrm{a}\left(\delta_{\mathrm{C}} 111.6\right)$, $\mathrm{C}-9\left(\delta_{\mathrm{C}} 148.1\right), \mathrm{C}-11\left(\delta_{\mathrm{C}} 116.7\right)$, and $\mathrm{C}-12\left(\delta_{\mathrm{C}} 154.3\right)$ and $\mathrm{H}-11$ with $\mathrm{C}-10\left(\delta_{\mathrm{C}} 123.1\right), \mathrm{C}-12\left(\delta_{\mathrm{C}} 154.3\right)$, and $\mathrm{C}-12 \mathrm{a}\left(\delta_{\mathrm{C}} 122.8\right)$ in the HMBC spectrum. The olefinic proton resonating at $\delta_{\mathrm{H}} 7.19$ was assigned as $\mathrm{H}-13$ based on HMQC and HMBC correlation. Further HMBC correlations were found from $\mathrm{H}-13$ to $\mathrm{C}-8 \mathrm{a}\left(\delta_{\mathrm{C}} 111.6\right), \mathrm{C}-12\left(\delta_{\mathrm{C}} 154.3\right), \mathrm{C}-12 \mathrm{a}\left(\delta_{\mathrm{C}} 122.8\right)$, and $\mathrm{C}-14\left(\delta_{\mathrm{C}} 134.5\right)$. Two singlet aromatic proton resonances at $\delta_{\mathrm{H}} 6.84$ and 6.64 were assigned to $\mathrm{H}-1 \quad\left(\delta_{\mathrm{C}} 112.1\right)$ and $\mathrm{H}-4\left(\delta_{\mathrm{C}} 111.9\right)$, respectively, on the basis of the HMBC correlations of $\mathrm{H}-1$ with $\mathrm{C}-2\left(\delta_{\mathrm{C}} 147.8\right), \mathrm{C}-3\left(\delta_{\mathrm{C}} 152.7\right)$, and C-4a $\left(\delta_{\mathrm{C}} 127.7\right)$ and H-4 with C-1a $\left(\delta_{\mathrm{C}} 126.3\right), \mathrm{C}-3\left(\delta_{\mathrm{C}} 152.7\right), \mathrm{C}-4 \mathrm{a}\left(\delta_{\mathrm{C}} 127.7\right)$, and C-5 $\left(\delta_{\mathrm{C}} 29.4\right)$. Consequently, the structure of $\mathbf{1}$ was elucidated and it was named amocurine A. 
Table 1. ${ }^{1} \mathrm{H}-\mathrm{NMR}\left(500 \mathrm{MHz}, \mathrm{CDCl}_{3}\right)$ Spectroscopic data for $\mathbf{1}-\mathbf{3}$

\begin{tabular}{|c|c|c|c|}
\hline position & $\mathbf{1}^{\mathrm{a}}$ & $2^{a}$ & $3^{a}$ \\
\hline 1 & $6.84 \mathrm{~s}$ & $6.86 \mathrm{~s}$ & \\
\hline \multicolumn{4}{|l|}{$1 \mathrm{a}$} \\
\hline \multicolumn{4}{|l|}{$1 \mathrm{~b}$} \\
\hline \multicolumn{4}{|l|}{2} \\
\hline 3 & & & $6.87 \mathrm{~s}$ \\
\hline \multicolumn{4}{|l|}{$3 a$} \\
\hline 4 & $6.64 \mathrm{~s}$ & $6.71 \mathrm{~s}$ & $3.19 \mathrm{t}(6.0)$ \\
\hline \multicolumn{4}{|l|}{$4 a$} \\
\hline 5 & $2.94 \mathrm{t}(6.0)$ & $\begin{array}{l}3.05 \mathrm{br} \mathrm{d}(15.7) \\
2.70 \mathrm{~m}\end{array}$ & $3.35 \mathrm{t}(6.0)$ \\
\hline 6 & $4.27 \mathrm{t}(6.0)$ & $\begin{array}{l}4.88 \text { br d (13.2) } \\
2.86 \text { br d (12.2) }\end{array}$ & \\
\hline \multicolumn{4}{|l|}{$6 a$} \\
\hline \multirow{2}{*}{\multicolumn{4}{|c|}{$\begin{array}{l}7 \\
7 \mathrm{a}\end{array}$}} \\
\hline & & & \\
\hline 8 & & & $6.98 \mathrm{~d}(9.0)$ \\
\hline \multicolumn{4}{|l|}{$8 \mathrm{a}$} \\
\hline 9 & & & $8.64 \mathrm{~d}(9.0)$ \\
\hline 10 & $7.36 \mathrm{~d}(8.4)$ & & \\
\hline 11 & $7.02 \mathrm{~d}(8.4)$ & $7.27 \mathrm{~d}(8.1)$ & \\
\hline \multicolumn{4}{|l|}{$11 \mathrm{a}$} \\
\hline 12 & & $6.99 \mathrm{~d}(8.1)$ & \\
\hline \multicolumn{4}{|l|}{$12 \mathrm{a}$} \\
\hline 13 & $7.19 \mathrm{~s}$ & $\begin{array}{l}3.14 \mathrm{dd}(15.3,3.1) \\
2.84 \mathrm{dd}(15.3,13.2)\end{array}$ & \\
\hline 14 & & $4.77 \mathrm{dd}(13.2,3.1)$ & \\
\hline $2-\mathrm{OCH}_{3}$ & $3.96 \mathrm{~s}$ & $3.95 \mathrm{~s}$ & \\
\hline $3-\mathrm{OCH}_{3}$ & $3.84 \mathrm{~s}$ & $3.84 \mathrm{~s}$ & \\
\hline $10-\mathrm{OCH}_{3}$ & & $3.89 \mathrm{~s}$ & $3.97 \mathrm{~s}$ \\
\hline $11-\mathrm{OCH}_{3}$ & & & $3.95 \mathrm{~s}$ \\
\hline $12-\mathrm{OCH}_{3}$ & $3.88 \mathrm{~s}$ & & \\
\hline $9-\mathrm{OH}$ & 13.15 br s & 13.12 br s & \\
\hline 7-CHO & & & $9.52 \mathrm{~s}$ \\
\hline $\mathrm{NCH}_{3}$ & & & $3.11 \mathrm{~s}$ \\
\hline $\mathrm{OCH}_{2} \mathrm{O}$ & & & $6.17 \mathrm{~s}$ \\
\hline
\end{tabular}

Amocurine B (2) was proposed to have the molecular formula $\mathrm{C}_{20} \mathrm{H}_{22} \mathrm{NO}_{5}$ based on HRESIMS. The ${ }^{1} \mathrm{H}$-NMR data (Table 1) revealed the presence of two ortho-coupled aromatic protons at $\delta_{\mathrm{H}} 7.27(\mathrm{~d}, J=8.1 \mathrm{~Hz}, \mathrm{H}-11)$ and $6.99(\mathrm{~d}, J=8.1 \mathrm{~Hz}, \mathrm{H}-12)$, two singlet aromatic protons at $\delta_{\mathrm{H}} 6.86$ $(\mathrm{H}-1)$ and $6.71(\mathrm{H}-4)$, and two methylene protons $\left[\delta_{\mathrm{H}} 3.05(\mathrm{br} \mathrm{d}, J=15.7 \mathrm{~Hz})\right.$ and $\left.2.70(\mathrm{~m})\right]$ and $\left[\delta_{\mathrm{H}}\right.$ 4.88 (br d, $J=13.2 \mathrm{~Hz}$ ) and 2.86 (br d, $J=12.2 \mathrm{~Hz}$ )], which are similar to those of amocurine A (1). The main difference found was the additional methine proton $\left[\delta_{\mathrm{H}} 4.77(\mathrm{dd}, J=13.2,3.1 \mathrm{~Hz}, \mathrm{H}-14)\right]$, which was coupled to two diastereotopic methylene protons $\left[\delta_{\mathrm{H}} 3.14(\mathrm{dd}, J=15.3,3.1 \mathrm{~Hz})\right.$ and 2.84 (dd, $J=15.3,13.2 \mathrm{~Hz})$ ] for compound 2 . This methylene group was situated at C-13 $\left(\delta_{\mathrm{C}} 37.1\right)$ by the observation of its HMQC and HMBC correlations of $\mathrm{H}-13$ to C-1a $\left(\delta_{\mathrm{C}} 127.4\right), \mathrm{C}-8 \mathrm{a}\left(\delta_{\mathrm{C}} 110.9\right), \mathrm{C}-12$ $\left(\delta_{\mathrm{C}} 115.1\right), \mathrm{C}-12 \mathrm{a}\left(\delta_{\mathrm{C}} 122.0\right)$, and $\mathrm{C}-14\left(\delta_{\mathrm{C}} 55.7\right)$ and between the aromatic proton $\mathrm{H}-12\left[\delta_{\mathrm{H}} 6.99(\mathrm{~d}, J\right.$ $=8.1 \mathrm{~Hz})]$ and $\mathrm{C}-13$. The methine proton $\left(\delta_{\mathrm{H}} 4.77\right)$ was located at $\mathrm{C}-14\left(\delta_{\mathrm{C}} 55.7\right)$ from the correlation between the singlet aromatic proton at $\delta_{\mathrm{H}} 6.86(\mathrm{H}-1)$ and C-14 in the HMBC spectrum. In addition, the HMBC correlations from H-11 to C-9 $\left(\delta_{\mathrm{C}} 144.8\right), \mathrm{C}-10\left(\delta_{\mathrm{C}} 150.3\right), \mathrm{C}-12\left(\delta_{\mathrm{C}} 115.1\right)$, and C-12a $\left(\delta_{\mathrm{C}}\right.$ $122.0)$ and from $\mathrm{H}-12$ to $\mathrm{C}-8 \mathrm{a}\left(\delta_{\mathrm{C}} 110.9\right), \mathrm{C}-10\left(\delta_{\mathrm{C}} 150.3\right), \mathrm{C}-11\left(\delta_{\mathrm{C}} 119.0\right)$, and $\mathrm{C}-12 \mathrm{a}\left(\delta_{\mathrm{C}} 122.0\right)$. The absolute configuration of $\mathrm{H}-14$ was determined as $S$, based on the negative of its specific rotation when compared to that of the related compound $(S)-(-)-2,3$-dimethoxy-8-oxoberbine, $[\alpha]_{D}-413.8(c$ 
0.36, $\mathrm{CHCl}_{3}$ ) [17], for which the structure was assigned using X-ray crystallography. Therefore, the structure of $\mathbf{2}$ was established, and it was named amocurine B.

Table 2. ${ }^{13} \mathrm{C}-\mathrm{NMR}$ Spectroscopic data for $\mathbf{1}-\mathbf{3}(125 \mathrm{MHz}, \delta$ in ppm)

\begin{tabular}{|c|c|c|c|}
\hline position & 1 & 2 & 3 \\
\hline 1 & 112.1 & 110.4 & 141.5 \\
\hline $1 \mathrm{a}$ & 126.3 & 127.4 & 117.3 \\
\hline $1 \mathrm{~b}$ & & & 127.5 \\
\hline 2 & 147.8 & 148.5 & 144.0 \\
\hline 3 & 152.7 & 150.2 & 106.7 \\
\hline $3 a$ & & & 126.2 \\
\hline 4 & 111.9 & 107.5 & 30.7 \\
\hline $4 a$ & 127.7 & 127.9 & \\
\hline 5 & 29.4 & 31.5 & 50.5 \\
\hline 6 & 39.1 & 37.9 & \\
\hline $6 a$ & & & 145.5 \\
\hline 7 & & & 110.2 \\
\hline $7 \mathrm{a}$ & & & 129.4 \\
\hline 8 & 166.3 & 165.5 & 108.4 \\
\hline $8 \mathrm{a}$ & 111.6 & 110.9 & \\
\hline 9 & 148.1 & 144.8 & 123.3 \\
\hline 10 & 123.1 & 150.3 & 150.1 \\
\hline 11 & 116.7 & 119.0 & 146.5 \\
\hline $11 \mathrm{a}$ & & & 118.5 \\
\hline 12 & 154.3 & 115.1 & \\
\hline $12 \mathrm{a}$ & 122.8 & 122.0 & \\
\hline 13 & 103.1 & 37.1 & \\
\hline 14 & 134.5 & 55.7 & \\
\hline $2-\mathrm{OCH}_{3}$ & 56.2 & 56.3 & \\
\hline $3-\mathrm{OCH}_{3}$ & 60.8 & 60.6 & \\
\hline $10-\mathrm{OCH}_{3}$ & & & 56.1 \\
\hline $11-\mathrm{OCH}_{3}$ & & & 60.5 \\
\hline $12-\mathrm{OCH}_{3}$ & 62.3 & 62.1 & \\
\hline \multicolumn{4}{|l|}{ 9-OH } \\
\hline 7-CHO & & & 188.5 \\
\hline $\mathrm{NCH}_{3}$ & & & 40.4 \\
\hline $\mathrm{OCH}_{2} \mathrm{O}$ & & & 100.8 \\
\hline
\end{tabular}

Amocurine C (3) was obtained as a dark brown gum. The molecular formula was established as $\mathrm{C}_{21} \mathrm{H}_{20} \mathrm{NO}_{5}$ by HRESIMS of the $[\mathrm{M}+\mathrm{H}]^{+}$at $m / z 366.1345$. The UV absorption bands at 265 and 329 $\mathrm{nm}$ indicated the presence of a benzenoid moiety and the IR spectrum exhibited a conjugated carbonyl absorption $\left(1684 \mathrm{~cm}^{-1}\right)$ and an aromatic ring system $\left(1592\right.$ and $\left.1512 \mathrm{~cm}^{-1}\right)$. The ${ }^{1} \mathrm{H}-\mathrm{NMR}$ spectrum (Table 1) showed the characteristic signals of a tetrahydroaporphinoid alkaloid [18] of a singlet $\mathrm{N}$ methyl proton $\left(\delta_{\mathrm{H}} 3.11\right)$, a singlet aromatic proton at $\delta_{\mathrm{H}} 6.87(\mathrm{H}-3)$, two ortho-coupled aromatic protons at $\delta_{\mathrm{H}} 8.64(\mathrm{~d}, J=9.0 \mathrm{~Hz}, \mathrm{H}-9)$ and $6.98(\mathrm{~d}, J=9.0 \mathrm{~Hz}, \mathrm{H}-8)$, one coupled methylene protons at $\delta_{\mathrm{H}} 3.35(\mathrm{t}, J=6.0 \mathrm{~Hz}, \mathrm{H}-5)$ and $3.19(\mathrm{t}, J=6.0 \mathrm{~Hz}, \mathrm{H}-4)$, and an aldehyde proton at $\delta_{\mathrm{H}} 9.52(\mathrm{~s}, \mathrm{H}-7)$. In addition, the spectrum displayed resonances due to two methoxy singlets at $\delta_{\mathrm{H}} 3.97\left(\mathrm{OCH}_{3}-10\right)$ and $3.95\left(\mathrm{OCH}_{3}-11\right)$ and a methylenedioxy proton $\left(\delta_{\mathrm{H}} 6.17, \mathrm{~s}\right)$. The ${ }^{13} \mathrm{C}-\mathrm{NMR}$ and DEPT spectra revealed the presence of 21 signals, including signals for a carbonyl carbon $\left(\delta_{\mathrm{C}} 188.5\right)$, a methylenedioxy carbon $\left(\delta_{\mathrm{C}} 100.8\right)$, two methylene carbons $\left(\delta_{\mathrm{C}} 50.5\right.$ and 30.7), three methine carbons $\left(\delta_{\mathrm{C}} 123.3,108.4\right.$, and 106.7), eleven quaternary carbons $\left(\delta_{\mathrm{C}} 150.1,146.5,145.5,144.0,141.5,129.4,127.5,126.2\right.$, $118.5,117.3$, and 110.2$)$, two methoxy carbons ( $\delta_{\mathrm{C}} 60.5$ and 56.1$)$, and $N$-methyl carbon $\left(\delta_{\mathrm{C}} 40.4\right)$. The 
spectroscopic data for $\mathbf{3}$ were similar to those of epiganine B [10], except that compound $\mathbf{3}$ showed two ortho-coupled aromatic protons $\left(\delta_{\mathrm{H}} 8.64\right.$ and 6.98). These aromatic protons were located at C-9 $\left(\delta_{\mathrm{C}} 123.3\right)$ and $\mathrm{C}-8\left(\delta_{\mathrm{C}} 108.4\right)$, respectively. The assignments of $\mathrm{H}-9$ and $\mathrm{H}-8$ were supported by the HMBC correlations from $\mathrm{H}-9$ to C-7a $\left(\delta_{\mathrm{C}} 129.4\right), \mathrm{C}-8\left(\delta_{\mathrm{C}} 108.4\right), \mathrm{C}-10\left(\delta_{\mathrm{C}} 150.1\right)$, and C-11 $\left(\delta_{\mathrm{C}} 146.5\right)$ and from H-8 to C-7 $\left(\delta_{\mathrm{C}} 110.2\right), \mathrm{C}-7 \mathrm{a}\left(\delta_{\mathrm{C}} 129.4\right), \mathrm{C}-9\left(\delta_{\mathrm{C}} 123.3\right), \mathrm{C}-10\left(\delta_{\mathrm{C}} 150.1\right)$, and C-11a $\left(\delta_{\mathrm{C}}\right.$ $118.5)$. Further HMBC correlations (Figure 2$)$ from the methylenedioxy unit to C-1 $\left(\delta_{\mathrm{C}} 141.5\right)$ and C-2 $\left(\delta_{\mathrm{C}} 144.0\right)$ and from the aldehyde proton $\left(\delta_{\mathrm{H}} 9.52\right)$ to $\mathrm{C}-6 \mathrm{a}\left(\delta_{\mathrm{C}} 145.5\right), \mathrm{C}-7\left(\delta_{\mathrm{C}} 110.2\right)$, and C-7a $\left(\delta_{\mathrm{C}}\right.$ 129.4), indicated that the methylenedioxy was positioned between $\mathrm{C}-1$ and $\mathrm{C}-2$ and the aldehyde group at C-7, respectively. Accordingly, the structure of $\mathbf{3}$ was elucidated, and it was named amocurine $\mathrm{C}$.

\subsection{Antiproliferative Activity}

All the compounds were evaluated for their in vitro antiproliferative activities against three human cancer cells, namely KB, MCF-7, and NCI-H187, using the MTT method (Table 3). In the antiproliferative activity assay, the aporphine alkaloid $\mathbf{3}$ showed significant antiproliferative activities against $\mathrm{KB}, \mathrm{MCF}-7$, and NCI-H187 cell lines with $\mathrm{IC}_{50}$ values 3.5, 4.2 and $6.7 \mu \mathrm{M}$, respectively. Compound 4 exhibited antiproliferative activities against KB, MCF-7, and NCI-H187 cells ( $\mathrm{IC}_{50}$ values $9.3,10.1$ and $8.5 \mu \mathrm{M}$, respectively), whereas compounds $\mathbf{1}, \mathbf{2}, \mathbf{5}$ and $\mathbf{6}$ displayed selective moderate antiproliferative activity against NCI-H187 cell line with $\mathrm{IC}_{50}$ values $20.5,40.2,30.4$ and $25.2 \mu \mathrm{M}$, respectively. These results implied that the antiproliferative activity observed were related to aporphine compounds with $\mathrm{C}_{6 \mathrm{a}}=\mathrm{C}_{7}$ and methylenedioxy functions, which corresponds to the result previously described by Likhitwitayawuid et al. [19] that aporphine alkaloids containing a 1,2methylenedioxy group are potent against cancer cell lines. Compounds $\mathbf{3}$ and $\mathbf{4}$ demonstrated stronger activity against cancer cell lines than compounds $\mathbf{5}$ and $\mathbf{6}$. These findings suggest that the aromatic ring system, $\mathrm{C}_{6 \mathrm{a}}=\mathrm{C}_{7}$, and 1,2-methylenedioxy ring as well as the planarity of structure have powerful effects on the antiproliferative activity.

Table 3. Antiproliferative activities of compounds 3-6 $\left(\mathrm{IC}_{50}, \mu \mathrm{M}\right)^{\mathrm{a}}$

\begin{tabular}{llll}
\hline Compounds & KB & MCF-7 & NCI-H187 \\
\hline $\mathbf{1}$ & $>50$ & $>50$ & $20.5 \pm 0.2$ \\
$\mathbf{2}$ & $>50$ & $>50$ & $40.2 \pm 0.5$ \\
$\mathbf{3}$ & $3.5 \pm 0.6$ & $4.2 \pm 1.4$ & $6.7 \pm 0.1$ \\
$\mathbf{4}$ & $9.3 \pm 0.8$ & $10.1 \pm 0.2$ & $8.5 \pm 0.5$ \\
$\mathbf{5}$ & $>50$ & $>50$ & $30.4 \pm 1.1$ \\
$\mathbf{6}$ & $>50$ & $>50$ & $25.2 \pm 0.8$ \\
Doxorubicin $^{\mathrm{b}}$ & $0.5 \pm 0.1$ & $6.8 \pm 0.1$ & $0.7 \pm 0.2$ \\
Ellipticine $^{\mathrm{b}}$ & $2.1 \pm 0.1$ & & $1.7 \pm 0.1$ \\
\hline
\end{tabular}

${ }^{a}$ Values are mean \pm standard deviation; mean of three assays

bositive control for antiproliferative activity assay

\section{Acknowledgments}

This research was financially supported by a grant from Prince of Songkla University, Thailand. We are grateful to Associate Professor Dr. Surat Laphookhieo, School of Science, Mae Fah Luang University for giving valuable suggestions, and to Associate Professor Dr. Seppo Karrila, Faculty of Science and Industrial Technology, Prince of Songkla University, for helpful comments and suggestions on our draft manuscript.

\section{Supporting Information}

Supporting information accompanies this paper on http://www.acgpubs.org/journal/records-ofnatural-products 


\section{ORCID}

Parinuch Chumkaew: 0000-0002-3924-2301

Passakorn Teerapongpisan: 0000-0002-6023-5704

Jaraslak Pechwang: 0000-0002-9357-397X

Theera Srisawat: 0000-0002-5467-1606

\section{References}

[1] N. Boonyapraphat, and C. Chockchaicharaenphorn (1998). Thai Medicinal Plants, Vol. II, Prachachon Ltd., Bangkok, pp 157-160.

[2] M. S. Abdelfattah, K. Toume, F. Ahmed, S. K. Sadhu and M. Ishibashi (2010). Cucullamide, a new putrescine bisamide from Amoora cucullata, Chem. Pharm. Bull. 58, 1116-1118.

[3] R. Pervin, S. Afrin, F. Sabrin, U. S. Zohora, M. S. Rahman, K. D. Islam and M. M. Billah (2016). Antioxidant, antibacterial and brine shrimp lethality bioassay of Amoora cucullata, a Mangrove plant, $J$. Young. Pharm. 8, 33-38.

[4] P. Chumkaew, C. Karalai, C. Ponglimanont and K. Chantrapromma (2003). Antimycobacterial activity of phorbol esters from the fruits of Sapium indicum, J. Nat. Prod. 66, 540-543.

[5] P. Chumkaew, S. Kato and K. Chantrapromma (2005). A new triterpenoid ester from the fruits of Bruguiera parviflora, Chem. Pharm. Bull. 53, 95-96.

[6] P. Chumkaew, S. Kato and K. Chantrapromma (2010). New cytotoxic steroids from the fruits of Syzygium siamense, J. Asian. Nat. Prod. Res. 12, 424-428.

[7] P. Chumkaew and T. Srisawat (2017). Antimalarial and cytotoxic quassinoids from the roots of Brucea javanica, J. Asian. Nat. Prod. Res. 19, 247-253.

[8] P. Chumkaew, J. Pechwang and T. Srisawat (2017). Two new antimalarial quassinoid derivatives from the stems of Brucea javanica, J. Nat. Med. 71, 570-573.

[9] P. Chumkaew, S. Kato and K. Chantrapromma (2006). Potent cytotoxic rocaglamide derivatives from the fruits of Amoora cucullata, Chem. Pharm. Bull. 54, 1344-1346.

[10] J. W. Dong, L. Cai, Y. S. Fang, H. Xiao, Z. J. Li and Z. T. Ding (2015). Proaporphine and aporphine alkaloids with acetylcholinesterase inhibitory activity from Stephania epigaea, Fitoterapia 104, $102-$ 107.

[11] B. Baghdikian, V. M. Leddet, S. Bory, S. S. Bun, A. Dumetre, F. Mabrouki, S. Hutter, N. Azas and E. Ollivier (2013). New antiplasmodial alkaloids from Stephania rotunda, J. Ethnopharmacol. 145, 381385 .

[12] T. H. Lee, M. J. Wang, P. Y. Chen, T. Y. Wu, W. C. Wen, F. Y. Tsai and C. K. Lee (2009). Constituents of Polyalthia longifolia var. pendula, J. Nat. Prod. 72, 1960-1963.

[13] Y. C. Ge, H. J. Zhang, K. W. Wang and X. F. Fan (2018). Aporphine alkaloids from Illigera aromatica from guangxi province, china, Phytochemistry 154, 73-76.

[14] H. N. Lyu, K. W. Zeng, N. K. Cao, M. B. Zhao, Y. Jiang and P. F. Tu (2018). Alkaloids from the stems and rhizomes of Sinomenium acutum from the qinling mountains, china, Phytochemistry 156, 241-249.

[15] V. Vichai and K. Kirtikara (2006). Sulforhodamine B colorimetric assay for cytotoxicity screening. Nat. Protoc. 1, 1112-1116.

[16] T. Promchai T, A. Jaidee, S. Cheenoracha, K. Trisuwan, R. Rattanajak, S. Kamchonwongpaisan, S. Laphookhieo, S. G. Pyne and T. Ritthiwigrom (2016). Antimalarial oxoprotoberberine alkaloids from the leaves of Miliusa cuneate, J. Nat. Prod. 79, 978-983.

[17] A. Gzella, M. Chrzanowska, A. Dreas and A. Froelich (2006). (S)-(-)-2,3-Dimethoxy-8-oxoberbine, Acta Crystallogr. Sect. E: Struct. Rep. Online. 62, o598-o600.

[18] J. W. Dong, X. J. Li, L. Cai, J. Y. Shi, Y. F. Li, C. Yang and Z. J. Li (2018). Simultaneous determination of alkaloids dicentrine and sinomenine in Stephania epigaea by ${ }^{1} \mathrm{H}$ NMR spectroscopy, $J$. Pharm. Biomed. Anal. 160, 330-335.

[19] K. Likhitwitayawuid, C. K. Angerhofer, H. Chai, J. M. Pezzuto and G. A. Cordell (1993). Cytotoxic and antimalarial alkaloids from the tubers of Stephania pierrei, J. Nat. Prod. 56, 1468-1478.

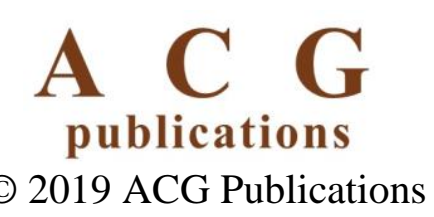

